\title{
Introductory address for the John Howland Award recipient, Elizabeth R. McAnarney, MD
}

\author{
Nina F. Schor ${ }^{1-3}$
}

$T_{P}$ his award was presented at the 2013 Annual Meeting of the Pediatric Academic Societies, Washington, DC.

It is truly an honor and a pleasure for me to speak to you today. I am grateful to the American Pediatric Society and especially to our 2013 Howland Award winner for this opportunity. As a scientist, I know that data are critically important, so I will do my best to present the data to you. But as a pediatrician, I know, too, that data are not sufficient, so I will also do my best to go beyond dates and names.

\section{THE EASY PART:THE FACTS}

As is always the case, the facts are the easy part. They simply are what they are-not subject to interpretation. Dr Elizabeth R. McAnarney, known to most as "Lissa," was born in Lenox Hill Hospital in New York City and raised in beautiful Watkins Glen, NY, on upstate New York's Seneca Lake. She is the youngest of three daughters (Mary, Kathryn, and Elizabeth) of Henry and Kathryn (Blaney) McAnarney. She obtained her A.B. from Vassar College and her M.D., cum laude, from the State University of New York Upstate Medical School in Syracuse (NY). Lissa stayed at State University of New York, Upstate Medical School for her residency in pediatrics and then moved to Rochester to pursue a fellowship in behavioral pediatrics. Her mentors throughout her residency and fellowship, including Julius Richmond, Stanford Friedman, Gilbert Forbes, Robert Haggerty, David Smith, and Robert Hoekelman, were to shape and validate her intrinsic penchant for going where no one had ever gone before and demanding academic rigor, intellectual integrity, and putting children first from everything she pursued.

Professionally, Dr McAnarney and her mentors literally coinvented the field of adolescent medicine. With her studies on adolescent pregnancy, she brought science to what had been presumption and speculation; she taught us that "unknown," "unfamiliar," and "unconventional" do not mean "bad" or even "high-risk." In the course of her own studies, she mentored the future thought leaders, not only specifically in adolescent medicine, but in community-based, child-focused research in general. Despite the potential for political or scholarly agendas to assume dominance in these areas, Lissa always made it clear to her colleagues, her trainees, and her detractors- "It must all be for the kids."

Her Textbook of Adolescent Medicine, co-edited with Drs Richard Kreipe and George Comerci, is a first-of-its-kind classic. Her work on adolescent pregnancy not only challenged the previous dogma-unencumbered-by-data, but also helped to launch the research careers of her trainees, including Drs Jill Halterman, Cassie Stevens-Simon, and Moira Szilagyi. Her most recent work on the neurobiology of anorexia nervosa brings the same rigorous study design, mentoring of junior co-investigators, and challenging of dogma to a subject more often thought of as psychosocial than as biological.

Along the way, Lissa's gentle manner, ready humor, and compassion have made her professional colleagues and mentees think of her as a close friend, indeed, as family. People like Drs Ruth Lawrence, O.J. Sahler, Peter Szilagyi, the late Caroline (Caren) Hall, Richard Kreipe, Philip Pizzo, Jonathan Klein, Thomas McInerny, and Joan and Russell Chesney are some of the leaders of pediatrics who form her Rochester-connected inner circle.

It is said that "Membership has its privileges." Dr McAnarney is an elected member of every esteemed society pediatrics and adolescent medicine have to offer. She is a member of the Institute of Medicine. But what sets her apart from the "rank and file" is that she has assumed leadership roles and launched innovative programs in her involvement with each of these organizations.

\section{THE HARD PART: THE ESSENCE}

If I had to capture the essence of Elizabeth R. McAnarney, MD, I would use a word taught to me by Lissa herself: generativity. That word embodies the attention to history and legacy, the focus on fueling the workforce pipeline, the consummate and constantly evolving expertise in mentoring, and the insistence that every answer evoke a half-dozen questions that so characterize Lissa's life and work. It is from these characteristics that arise humility, graciousness, creativity, and curiosity-all qualities that mark Dr McAnarney at once as a leader, a mentor, and a friend. How rare to find humor and intellectual depth, 


\section{Special Article | schor}

breadth of interest and focus of accomplishment, singular preeminence and modesty all in one person!

\section{THE BEST PART: LISSA}

But the best part of all, of course, is Lissa herself. Everything Lissa is, does, and admires is all about the kids. Unless it is about her beloved Yankees! In honor of her selfless dedication to children, their families and communities, and those who care for them now and in the future, the board of the
Golisano Children's Hospital at the University of Rochester Medical Center (Rochester, NY) named one of the friends of its mascot, Sandy Strong, "Lissa". Surely, the only honor that can be greater than this is the bestowing upon $\mathrm{Dr}$ McAnarney of the Howland Award by the American Pediatric Society.

Ladies and gentlemen, it is with great honor, pride, and admiration that I present to you the 2013 Howland Awardee, Dr Elizabeth R. McAnarney. 